\title{
PENERAPAN MODEL PEMBELAJARAN BILINGUAL PREVIEW-REVIEW BERBASIS E-FLASHCARD UNTUK MENINGKATKAN AKTIVITAS DAN PRESTASI BELAJAR BAHASA INGGRIS SISWA SMP
}

\author{
Maria Desidaria Noge \\ STKIP Citra Bakti, Nusa Tenggara Timur \\ ennynoge@gmail.com
}

\begin{abstract}
Abstrak
Penelitian ini bertujuan untuk mengetahui peningkatan kemampuan berbahasa Inggris siswa SMP. Secara spesifik, penelitian ini fokus untuk: (1) mengetahui peningkatan aktivitas belajar siswa SMP dengan menerapkan model pembelajaran Bilingual Preview-Review berbasis E-Flashcard dan (2) mengetahui peningkatan prestasi belajar siswa SMP dengan menerapkan model pembelajaran Bilingual Preview-Review berbasis E-Flashcard. Penelitian ini merupakan Penelitian Tindakan Kelas (PTK) menggunakan model Kemis dan Mc Taggart (Kusuma dan Dwitagama, 2010: 20). Penelitian ini dilaksanakan di SMPS Yos Soedarso Jerebuu kelas VIII. Data yang dikumpulkan dalam penelitian ini adalah aktivitas belajar berupa lembar observasi dan prestasi belajar berupa tes lisan. Data hasil penelitian dianalisis secara statistik deskriptif kuantitatif. Hasil penelitian menunjukkan: (1) model pembelajaran Bilingual Preview-Review berbasis E-Flashcard dapat meningkatkan aktivitas belajar siswa yakni pada siklus I dengan rata-rata aktivitas siklus I yaitu 12 berada pada kategori tidak aktif, persentase aktivitas $48 \%$,dan rata-rata aktivitas belajar siklus II 21, berada pada kategori sangat aktif; (2) model pembelajaran Bilingual Preview-Review berbasis E-Flashcard dapat meningkatkan hasil belajar siswa yakni pada siklus I prestasi belajar memperoleh rata-rata sebesar 53,06 berada pada kategori cukup, persentase 53,06\%, ketuntasan klasikal 33,33\% dan siklus II rata-rata prestasi belajar 81,11, ketuntasan klasikal 83,33\%. Berdasarkan temuan hasil penelitian di atas, dapat disimpulkan bahwa penerapan model pembelajaran Bilingual Preview-Review berbasis E-Flashcard dapat meningkatkan kemampuan berbahasa Inggris siswa.
\end{abstract}

Kata-kata kunci: Bilingual Preview-Review, E-Flashcard, aktivitas belajar, hasil belajar

\begin{abstract}
The research aimed to know the improvement of Junior High School student's English speaking ability. Specifically, this research concerned on: (1) knowing the improvement of Junior High School students learning activity by applying Bilingual preview-review teaching and learning model through E-Flashcard and (2) knowing the improvement of Junior High School students learning achievement by applying Bilingual preview-review teaching and learning model through E-Flashcard. This research was the Classroom Action Research (CAR) by using Kemis and Mc Taggart model (Kusuma dan Dwitagama, 2010: 20). This research has been done for the students of grade VIII in second term in SMPS Yos Soedarso Jerebuu. The data collected in this research was learning activity in the form of observation sheet and learning achievement in the form of oral test. Data of research analyzed statistically descriptive quantitative. The research results showed: ( 1 ) Bilingual previewreview teaching and learning model through E-Flashcard can improve the students' learning activity in cycle I with an average activity in cycle I that is 12 being in inactive category, the percentage of activity $48 \%$, and the average learning activity cycle II 21 , being in very active category; (2) Bilingual preview-review teaching and learning model through E-Flashcard can improve students' learning achievement in cycle I learning achievement got an average of 53.06 being in enough category, the percentage $53.06 \%$, classical completeness $33.33 \%$ and cycle II the average of learning achievement 81.11 , classical completeness $83.33 \%$. Based on the findings research upon, it can be concluded that the application Bilingual preview-review teaching and learning model through EFlashcard can improve Junior High School students’ English speaking ability.
\end{abstract}

Keywords: Bilingual preview-review, E-Flashcard, learning activity, learning achievement 


\section{Pendahuluan}

Pendidikan merupakan kunci kemajuan dan kesuksesan masa depan dari suatu bangsa. Dengan sistem pendidikan yang baik dapat meningkatkan mutu pendidikan yang dapat menciptakan sumber daya manusia yang berkualitas. Sebagaimana dinyatakan pada pasal 1 Undang Undang No. 20/2003 tentang Sistem Pendidikan Nasional bahwa pendidikan adalah usaha sadar dan terencana untuk mewujudkan suasana belajar dan proses pembelajaran agar peserta didik secara aktif mengembangkan potensi dirinya untuk memiliki kekuatan spiritual keagamaaan, pengendalian diri, kepribadian, kecerdasan, akhlak mulia, serta keterampilan yang diperlukan dirinya, masyarakat, bangsa dan negara. Selain itu, dalam arti yang luas pendidikan diartikan sebagai sebuah proses dengan metode-metode tertentu sehingga orang memperoleh pengetahuan, pemahaman dan 'cara bertingkah laku yang sesuai dengan kebutuhan, Muhibinsya (dalam Sagala, 2012:10).

Memasuki era globalisasi yang semakin berkembang, bahasa juga mengalami perkembangan dan perubahan yang semakin pesat. Perubahan yang terjadi pada masa ini disebabkan oleh tingginya produktivitas di negara-negara maju, sedangkan di negara-negara berkembang justru rendah produktivitasnya. Hal ini perlu dibuktikan dengan diwujudkannya sumber daya manusia yang cerdas, kreatif, berbudaya, dan berkompeten serta berdaya saing baik secara nasional maupun secara internasional. Upaya-upaya telah dilakukan oleh setiap negara untuk meningkatkan sumber daya manusia tersebut. Salah satu upaya yang dilakukan dalam dunia pendidikan di masing-masing negara adalah dengan menyelenggarakan program pembelajaran bilingual sejak usia dini sampai pada tingkat perguruan tinggi. Menghadapi tuntutan ini, bangsa Indonesia memerlukan kemampuan dan kompetensi yang tinggi untuk mengelola berbagai dampak dari perkembangan global dan teknologi terhadap pendidikan di Indonesia.

Dalam dunia pendidikan Indonesia saat ini, pembelajaran Bilingual diselenggarakan dalam setiap mata pelajaran di semua level pendidikan. Ini sangat membantu pebelajar untuk memahami materi ajar dalam dua bahasa, sehingga tidak mengalami kesulitan dalam dunia kerja nantinya. Pembelajaran bilingual menjadi proses pembelajaran yang semakin ramai ditingkatkan dan dikembangkan dalam bidang pendidikan. Maka pendidik perlu mendalami dan mempelajari secara baik pembelajaran bilingual dan mengimpelmentasikannya secara tepat pula agar setiap proses pembelajaran dapat berlangsung secara efektif dan efisien dengan menggunakan dua bahasa.

Arnyana, (dalam Paraniti, 2012) menyebutkan bahwa tujuan pembelajaran bilingual di Indonesia adalah: (1) meningkatkan penguasaan materi pelajaran, (2) meningkatkan kemampuan berbahasa Inggris dalam forum ilmiah maupun non-ilmiah, (3) mampu mengakses pengetahuan ilmiah dari berbagai media internasional, dan (4) mampu berkomunikasi antar siswa baik dari dalam maupun luar negeri. Bertitik tolak pada pernyataan ini, maka sarana dan prasarana, perangkat pembelajaran, sistem pembelajaran, dan media pembelajaran merupakan alat ukur dalam meningkatkan keberhasilan pembelajaran Bilingual. Tanpa adanya alat ukur di atas, maka karakteristik dari pembelajaran yang diimplementasikan akan menjadi pudar. Perangkat pembelajaran bilingual yang digunakan saat ini belum mampu dioptimalkan secara baik, sehingga masih perlu diperbaiki dan dilengkapi secara baik.

Pembelajaran bilingual merupakan pembelajaran yang diterapkan dengan menggunakan dua bahasa, dalam hal ini bahasa Indonesia dan bahasa Inggris. Bahasa Inggris dbahasa Inggrisndang perlu untuk dipelajari karena bahasa Inggris merupakan bahasa internasional dan bahasa pergaulan dunia, artinya bahwa bahasa Inggris merupakan alat komunikasi secara internasional. Sehingga diharapkan dengan adanya pembelajaran bilingual dapat menghasilkan manusia yang berkompeten dan berdaya saing pada tingkat nasional maupun internasional. Namun perlu disadari juga bahwa penguasaan bahasa asing bagi sebagian masyarakat Indonesia masih sangatlah rendah, termasuk rendahnya kemampuan berkomunikasi dalam bahasa Inggris baik secara lisan maupun tertulis.

Menurut Harry (2008), model-model pembelajaran bilingual inovatif sangat diperlukan oleh guru untuk dijadikan suatu referensi dan pedoman dalam melaksanakan pembelajaran bilingual di kelas. Salah satu model pembelajaran inovatif yang dapat diterapkan dalam pembelajaran bilingual adalah model pembelajaran bilingual preview-review (Paraniti, 2012). Model pembelajaran bilingual 
preview-review secara terpisah memiliki tiga tahapan pelaksanaan pembelajaran. (Ovando, 1985; Banks, 1988) menyatakan tahapan pelaksanaan pembelajaran preview-review sebagai berikut: (1) Pembelajaran tahap pertama oleh guru I, dengan menggunakan bahasa ke-1 (misalnya Bahasa Indonesia); (2) Pembelajaran tahap kedua dilanjutkan oleh guru II dengan bahasa ke-2 (misalnya bahasa Inggris); dan (3) Pembelajaran tahap ketiga peninjauan dan reinforcement, secara klasikal menggunakan kedua bahasa secara bergantian (campuran).

Di sisi lain, media pembelajaran juga merupakan perangkat pembelajaran yang penting untuk diperhatikan secara baik. Menurut Tirtayani, Magta, Lestari (2017), "Media 'teacher friendly eflashcards is a technology-based educational media that can be used in bilingual teaching of children". Muhson (2010) menyatakan bahwa "Teaching media is a tool that can be manipulated and can be used to effect students' mind, feeling, attention, and attitude, so it can help the learning process become easier". Dapat diartikan bahwa media pembelajaran merupakan alat yang dapat dimanipulasi dan bisa digunakan untuk memberikan efek pada pikiran, perasaan, perhatian, dan sikap siswa, sehingga dapat membantu proses pembelajaran menjadi lebih mudah.

Hal inilah yang dialami oleh para siswa khususnya siswa SMP pada umumnya, di mana pemahaman tentang pentingnya bahasa Inggris masih sangat rendah sehingga siswa tidak memiliki motivasi, minat dan keinginan untuk mempelajari dan mendalami materi dengan menggunakan bilingual. Siswa cenderung malas dan tidak kreatif jika mata pelajaran yang diajarkan kebanyakan mulai menggunakan Bilingual, karena mereka memiliki pemahaman bahwa sangatlah sulit memahami materi dengan menggunakan bahasa Indonesia apalagi dengan menggunakan bahasa asing. Apalagi media yang digunakan kurang membangkitkan semangat siswa untuk belajar. Namun hampir semua mata pelajaran telah diimplementasikan dalam dua bahasa termasuk bahasa Inggris, artinya bahwa pembelajaran bilingual menjadi sangatlah penting bagi para siswa demi meningkatkan kualitas dan kompetensi serta berdaya saing tinggi sehingga menghasilkan lulusan yang handal, mempunyai daya saing Internasional tetapi tidak meninggalkan ciri khas Bangsa Indonesia yang berbudi pekerti luhur, jujur dan mempunyai jiwa patriotisme yang tinggi. Pembelajaran bilingual memang telah didapat namun belum bisa diimpementasikan secara baik dalam setiap mata pelajaran, sehingga perlu mendapat perhatian yang cukup agar dapat menerapkan pembelajaran ini secara tepat guna (usefull) dan lebih menekankan pada proses dinamis yang didasarkan pada upaya meningkatkan keingintahuan (curiosity) siswa tentang dunia.

Berdasarkan paparan di atas, kemampuan siswa dalam berbahasa Inggris dipengaruhi oleh ketepatan guru dalam menerapkan model pembelajaran, sumber belajar lebih khusus model dan media pembelajaran yang inovatif dan kreatif sehingga berdampak pada kemampuan siswa menerima pelajaran secara efektif dan efisien serta menyenangkan. Maka perlu diupayakan agar pembelajaran Bilingual dapat diimplemetasikan secara holistik dalam seluruh proses pembelajaran di setiap mata pelajaran. Oleh karena itu, penelitian ini dilakukan untuk mengetahui kemampuan berbahasa Inggris siswa SMP dengan menerapkan model pembelajaran Bilingual Preview-Review berbasis E-Flashcard. Tujuan penelitian ini adalah untuk: (1) mengetahui peningkatan aktivitas belajar siswa SMP dengan menerapkan model pembelajaran Bilingual Preview-Review berbasis E-Flashcard dan (2) mengetahui peningkatan prestasi belajar siswa SMP dengan menerapkan model pembelajaran Bilingual PreviewReview berbasis E-Flashcard.

\section{Metode}

Jenis Penelitian ini adalah penelitian tindakan kelas (PTK) yang menggunakan model penelitian Kemis dan Mc Taggart (Kusuma dan Dwitagama, 2010: 21). Model Mc Taggart ini terdiri dari empat komponen yang berurutan yaitu perencanaan, tindakan, pengamatan dan refleksi, yang dalam pelaksanaan dan pengamatannya dilakukan secara bersamaan. Artinya pengamatan dilakukan pada saat proses pembelajaran. Subjek dalam penelitian ini adalah siswa-siswi kelas VIII SMPS Yos Soedarso, yang berjumlah 30 orang siswa, yang terdiri dari 12 orang siswa perempuan dan 18 orang siswa laki- 
laki. Subjek penelitian ini sangat heterogen dilihat dari kemampuannya, yakni ada sebagian siswa yang memiliki kemampuan yang tinggi, sedang dan rendah.

Penelitian ini ditempuh melalui Penelitian Tindakan Kelas (PTK) melalui siklus-siklus. Prosedur penelitian ini dilaksanakan dalam dua siklus yaitu siklus I dan siklus II dengan mengacu pada desain Kemis dan Mc Taggart yang meliputi 4 tahap. Tahap-tahap pada siklus I adalah sebagai berikut. 1) Perencanaan

Pada tahap perencanaan langkah-langkah yang dilakukan adalah sebagai berikut: merencanakan waktu pelaksanaan untuk penelitian tindakan kelas, berkonsultasi dengan guru kelas berkaitan dengan perangkat pembelajaran dan jadwal pembelajaran, menentukan standar kompetensi, kompetensi dasar, indikator dan tujuan pembelajaran, menyusun rencana pelaksanaan pembelajaran (RPP) yang berfokus pada langkah-langkah pembelajaran dan penerapan model pembelajaran Bilingual Preview-Review berbasis E-Flashcard dengan mengoptimalkan waktu yang tersedia seefektif mungkin, menyiapkan media pembelajaran yang dibutuhkan yakni E-Flashcard yang berisi konten materi pembelajaran, membuat lembar kerja siswa (LKS) sesuai dengan jumlah kelompok siswa, menyusun alat evaluasi yaitu berupa lembar observasi dan tes untuk menilai hasil belajar siswa dan membuat format penilaian.

2) Pelaksanaan atau Tindakan

Tahap ini merupakan tahap melaksanakan proses pembelajaran di kelas. Dalam pelaksanaan pembelajaran ini mengikuti pedoman yang ada dalam RPP yang berfokus pada penerapan model pembelajaran Bilingual Preview-Review berbasis E-Flashcard. Adapun langkah-langkah pembelajaran yaitu: kegiatan awal menggunakan bahasa Indonesia: (1) doa; (2) guru melakukan presensi terhadap kehadiran siswa; (3) guru melakukan apersepsi dengan tujuan untuk menggali pemahaman awal siswa mengenai materi; (4) guru memberikan motivasi belajar tentang materi dan menyampaikan tujuan pembelajaran serta kegiatan yang akan dilakukan; kegiatan inti menggunakan bahasa Inggris: (5) guru menjelaskan materi dengan menggunakan E-Flashcard; (6) guru membagi siswa secara berkelompok; (7) guru membagi lembar kerja siswa (LKS) pada setiap kelompok berupa E-Flashcard; (7) guru mendampingi siswa mengerjakan LKS di dalam kelompok; (8) guru meminta siswa untuk melaporkan hasil diskusi di depan kelas; kegiatan akhir menggunakan dua bahasa secara bergantian (9) guru bertanya hal-hal yang belum dipahami siswa; (10) guru bersama siswa menyimpulkan materi yang telah dipelajari dan melakukan evaluasi; (11) doa penutup.

3) Tahap Observasi

Pada tahap ini, hal yang dilakukan adalah mengamati aktivitas siswa selama proses pembelajaran berlangsung dengan menggunakan lembar observasi yang sudah disediakan. Observasi dilakukan untuk mengetahui kekurangan dan kelebihan setiap siswa, sehingga dapat melaksanakan tindakan selanjutnya.

4) Refleksi

Pada tahap ini hasil belajar siswa dianalisis, didiskusikan dan dievaluasi. Hal ini bertujuan untuk menemukan kelebihan ataupun kelemahan proses pembelajaran dan hasil belajar yang dicapai siswa. Hasil refleksi ini akan menjadi bahan rekomendasi untuk pelaksanaan siklus berikutnya.

\section{Hasil dan Pembahasan}

Penelitian dilaksanakan dalam 2 siklus, dimana setiap siklus dilaksanakan dalam 3 kali pertemuan yaitu 2 kali pertemuan untuk pembelajaran dan 1 kali pertemuan untuk tes. Data yang dikumpulkan dalam penelitian ini, yaitu data tentang aktivitas dan prestasi belajar siswa. Data yang telah dikumpulkan dianalisis sesuai dengan teknik analisis data yang telah ditetapkan sebelumnya.

\section{1) Siklus I}

Pada siklus I; (1) tahap perencanaan dilakukan dengan cara menyiapkan silabus, RPP, serta materi yang sesuai dengan model pembelajaran Bilingual Preview-Review berbasis E-Flashcard dengan memperhatikan Standar Kompetensi mata pelajaran bahasa Inggris. Di samping itu juga, pada 
tahap ini disiapkan media pembelajaran, instrumen penilaian atau tes dan lembar observasi; (2) tahap tindakan dilakukan dengan menerapkan skenario sesuai dengan sintaks pembelajaran Bilingual Preview-Review berbasis E-Flashcard yang telah disiapkan dan atas persetujuan guru Bahasa Inggris kelas VIII di SMPS Yos Soedarso dalam proses kegiatan belajar mengajar. Pada siklus I dilaksanakan dalam 2 kali pertemuan sesuai dengan Rencana Pelaksanaan Pembelajaran (RPP) model pembelajaran Bilingual Preview-Review berbasis E-Flashcard; (3) tahap observasi dilakukan dengan mengumpulkan data observasi untuk mengamati aktivitas siswa selama proses pembelajaran berlangsung serta memberi nilai kognitif siswa setelah mengikuti proses pembelajaran. Prestasi belajar diperoleh dari nilai kognitif hasif belajar siswa.; dan (4) tahap refleksi dilakukan dengan cara merefleksi kekurangan dan kelebihan untuk ditindaklanjuti. Aktifitas siswa pada siklus I yaitu siswa belum berani mengajukan pertanyaan terkait kesulitan yang dialaminya selama proses pembelajaran, siswa kurang aktif dalam diskusi mengenai masalah yang ditemukan dalam proses pembelajaran, siswa belum berani mengemukan pendapat terkait materi pelajaran, dan siswa belum memiliki kemauan untuk belajar secara efektif menggunakan model pembelajaran yang disediakan. Berdasarkan hasil diatas maka terdapat hal yang perlu diperhatikan dan diperbaiki. Untuk itu perlu adanya tindak lanjut untuk menjawab kekurangan-kekurangan diatas. Dengan demikian penelitian ini dilanjutkan pada siklus II dengan cara menerapkan kembali model pembelajaran Bilingual Preview-Review berbasis E-Flashcard tetapi dalam proses pembelajaran diubah cara atau strategi dalam mengajar sehingga siswa lebih aktif dan antusisas dalam mengikuti proses pembelajaran.

\section{2) Siklus II}

Pada siklus II, (1) pada tahap perencanaan dilakukan dengan cara yang sama pada siklus I yaitu dengan cara menyiapkan silabus, RPP, serta materi yang sesuai dengan model pembelajaran Bilingual Preview-Review berbasis E-Flashcard dengan memperhatikan Standar Kompetensi mata pelajaran bahasa Inggris. Di samping itu juga, pada tahap ini disiapkan media pembelajaran, instrumen penilaian atau tes dan lembar observasi; (2) tahap tindakan dilakukan dengan menerapkan skenario sesuai dengan sintaks pembelajaran Bilingual Preview-Review berbasis E-Flashcard yang telah disiapkan dan atas persetujuan guru Bahasa Inggris kelas VIII di SMPS Yos Soedarso dalam proses kegiatan belajar mengajar. Pada siklus II dilaksanakan dalam 2 kali pertemuan juga sesuai dengan Rencana Pelaksanaan Pembelajaran (RPP) model pembelajaran Bilingual Preview-Review berbasis EFlashcard. Pada siklus ini, materi dan media yang disajikan dengan sangat menarik, kreatif dan inovatif demi menumbuhkan semangat belajar yang tinggi bagi para siswa; (3) tahap observasi dilakukan dengan mengumpulkan data observasi untuk mengamati aktivitas siswa selama proses pembelajaran berlangsung serta memberi nilai kognitif siswa setelah mengikuti proses pembelajaran. Prestasi belajar diperoleh dari nilai kognitif hasif belajar siswa.; dan (4) tahap refleksi dilakukan dengan cara merefleksi kekurangan dan kelebihan untuk ditindaklanjuti. Hasil refleksi pelaksanaan pembelajaran siklus II adalah sebagai berikut: siswa berani mengajukan pertanyaan terkait kesulitan yang dialaminya selama proses pemebalajaran.Kegiatan pembelajaran siswa juga mengalami peningkatan pada siklus II karena semua siswa sudah terlibat dalam kegiatan pembelajaran atau aktif dalam proses pembelajaran dan penuh semangat yang tinggi, sehingga hasil yang diperoleh pun sangat memuaskan.

Dari hasil penelitian siklus I terlihat bahwa rata-rata aktivitas belajar bahasa Inggris sebesar 12 berada pada kategori tidak aktif, persentasenya 48\%. Hal ini menunjukan bahwa tingkat keaktifan siswa dalam mengikuti pembelajaran dengan model pembelajaran Bilingual Preview-Review berbasis E-Flashcard berada pada kategori tidak aktif berdasarkan kategori yang ditetapkan dalam skala lima teoritik. Sedangkan prestasi belajar bahasa Inggris pada siswa kelas VIII di SMP Yos Soedarso dengan rata-rata sebesar 53,06, ketuntasan Klasikal 33, 33\%, presentasenya sebesar 53,06\%. Dengan demikian proses pembelajaran pada siklus I dinyatakan siswa belum tuntas.

Dari hasil penelitian siklus II menunjukan bahwa tingkat keaktifan siswa dalam mengikuti pembelajaran dengan menggunakan model pembelajaran Bilingual Preview-Review berbasis EFlashcard dengan rata-rata 21 berada pada kategori sangat aktif berdasarkan kategori yang ditetapkan dalam skala lima teoritik. Sedangkan hasil penelitian siklus II dapat dilihat bahwa prestasi belajar 
siswa kelas VIII SMPS Yos Soedarso meningkat sebanyak 28,05 \% dari hasil evaluasi siklus I. Pada siklus II prestasi belajar siswa sudah mencapai KKM yang ditetapkan di sekolah yaitu 66. Prestasi belajar siswa pada siklus II menunjukan dengan rata-rata 81,11, KK 83, 33\%, persentase $81,11 \%$ dan 15 siswa yang tuntas. Pada siklus II dinyatakan tuntas dan berada pada kategori sangat baik serta siswa memahami materi yang diberikan oleh guru dengan menggunakan model pembelajaran Bilingual Preview-Review berbasis E-Flashcard.

Hasil pembahasan yang menunjukan peningkatan aktivitas dan prestasi belajar dapat diamati melalui tabel dibawah ini:

Tabel 1 Data Aktivitas dan Prestasi Belajar Bahasa Inggris Siswa

\begin{tabular}{|l|l|l|l|}
\hline \multicolumn{1}{|c|}{ Uraian } & \multicolumn{1}{c|}{ Siklus I } & \multicolumn{1}{c|}{ Siklus II } & \multicolumn{1}{c|}{ Peningkatan } \\
\hline Rata-rata total aktivitas & 12 & 21 & 16,5 \\
\hline Rata-rata Aktivitas & 12 & 21 & $54,54 \%$ \\
\hline persentase Aktivitas & $48 \%$ & $84 \%$ & \\
\hline Rata-rata total prestasi belajar & 53,06 & 81,11 & 67,08 \\
\hline Rata-rata Prestasi Belajar & 53,06 & 81,11 & $41,81 \%$ \\
\hline Persentase Belajar & $53,06 \%$ & $81,11 \%$ & \\
\hline Ketuntasan Klasikal & $33,33 \%$ & $83,33 \%$ & $50 \%$ \\
\hline
\end{tabular}

Tabel di atas menunjukan data hasil pencapaian aktivitas belajar dan prestasi belajar siswa pada siklus I dan siklus II. Data tersebut menunjukan adanya peningkatan aktivitas belajar dan prestasi belajar pada siklus I dan siklus II, dimana pada siklus I aktivitas belajar siswa mencapai skor rata-rata 12 berada pada kategori tidak aktif berdasarkan skala lima teoritik dengan persentase yang dicapai $48 \%$. Sedangkan untuk prestasi belajar mencapai rata-rata 53,06 dan persentase 53,06\% berada pada kategori kurang berdasakan PAP yang ditetapkan, sedangkan ketuntasan klasikal 33,33\% dari KKM yang ditetapkan yaitu 66. Peningkatan aktivitas dan prestasi belajar terjadi pada siklus II dimana aktivitas belajar meningkat dari rata-rata skor 12 menjadi 21 dan persentase meningkat sebanyak $36 \%$ dari $48 \%$ menjadi $84 \%$. Sedangkan untuk prestasi belajar mengalami peningkatan sebanyak $28,05 \%$ dari 53,06\% menjadi 81,11\% dan ketuntasan klasikal dari 33,33\% menjadi 83,33\%.

Dilihat dari hasil observasi kegiatan siswa pada siklus I tidak aktif. Menurut data yang diperoleh menunjukan bahwa aktivitas belajar siswa dalam proses pembelajaran pada siklus I belum memenuhi standar. Dengan memperhatikan data pada siklus I, penelitian tetap dilanjutkan pada siklus II dengan melihat kekurangan-kekurangan atau hambatan-hambatan pada siklus I. Hal ini terbukti dari refleksi siklus I masih terdapat kekurangan-kekurangan atau hambatan-hambatan dalam pelaksanaan tindakan. Berdasarkan kekurangan atau hambatan yang dihadapi pada siklus I, dan untuk memperbaiki atau meningkatkan aktivitas dan prestasi belajar yang sesuai dengan tuntutan kurikulum, maka pada siklus II diberikan tindakan perbaikan dengan memberikan penekanan kepada siswa agar lebih baik dan disosialisasikan kembali penerapan model pembelajaran Bilingual Preview-Review berbasis e_Flashcard kepada siswa.

Jadi, berdasarkan hasil pembahasan dapat disimpulkan bahwa penerapan model pembelajaran Bilingual Preview-Review berbasis $e_{-}$Flashcard terbukti dapat meningkatkan aktivitas dan prestasi belajar Bahasa Inggris pada siswa kelas VIII SMPS Yos Soedarso, dengan peningkatan aktivitas belajar siswa sebesar 54,54\%, prestasi belajar sebesar 41,81\% dan ketuntasan klasikal sebesar 50\%.

\section{Penutup}

Berdasarkan analisis data dan pembahasannya di atas dapat disimpulkan bahwa: (1) Model pembelajaran Bilingual Preview-Review berbasis E-Flashcard dapat meningkatkan aktivitas belajar Bahasa Inggris pada siswa kelas VIII SMPS Yos Soedarso yaitu pada siklus I dengan rata-rata aktivitas siklus I yaitu 12 berada pada kategori tidak aktif, persentase aktivitas 48\%,dan rata-rata aktivitas belajar siklus II 21, berada pada kategori sangat aktif, persentase aktivitas $84 \%$. Rata-rata total 
peningkatan aktivtas dari siklus I ke Siklus II sebesar 16,5, sedangkan peningkatan persen aktivitas dari siklus I ke siklus II sebesar 54,54\% atau $21-12=9=54,54 \%(9 / 16,5 \times 100 \%=54,54 \%)$; (2) Model pembelajaran Bilingual Preview-Review berbasis E-Flashcard dapat meningkatkan prestasi belajar Bahasa Inggris pada siswa kelas VIII SMPS Yos Soedarso yaitu pada siklus I prestasi belajar memperoleh rata-rata sebesar 53,06 berada pada kategori cukup, persentase 53,06\%, ketuntasan klasikal 33,33\% dan siklus II rata-rata prestasi belajar 81,11, ketuntasan klasikal 83,33\%, persentase prestasi belajar sebesar $84 \%$. Rata-rata total peningkatan prestasi belajar dari siklu I ke siklus II sebesar 67,08 , sedangkan peningkatan persen prestasi belajar dari siklus I ke siklus II sebesar $41,81 \%$ $=81,11-53,06=28,05=(28,05 / 67,085 \times 100 \%=41,81 \%)$. Dan ketuntasan belajar meningkat dari siklus I ke siklus II sebesar $50 \%=83,33 \%-33,33 \%=50 \%$

\section{Daftar Pustaka}

Aliponga, J. \& Johnston, C.C. (2013). Benefits of Using Vocbulary Flash Cards in an EFL Classroom. Summary of Research, 14, 1-6

Arnyana, I. B. Putu. 2006. Pengembangan Model Pembelajaran Bilingual Preview-Review Dipandu Strategi STAD dalam Pembelajaran Sains di SMA. Jurnal Pendidikan dan Pengajaran UNDIKSHA, No 2 TH.XXXXI.

Cohen, A. D. and Swain, M. 1976. Bilingual education: The Immersion Model in the North AMERICAN context. TESOL Quartenly. 10(1). 45-53.

Harry. 2008. Pembelajaran Matematika dan IPA dalam Bahasa Inggris di SMP. Artikel.Tersedia pada http://203.130.242.190/artikel/105. Artikel ini diakses pada tanggal 16 September 2016.

http://ejournal.undiksha.ac.id/index.php/JET/article/viewFile/10080/6416

Krcelic, P. \& Skledar Matijevic, A. (2015). A picture and a thousand words: Visual tools in ELT. The Internasional Conference on The Importance of Learning Professional Foreign Languages for Communication between Cultures. p. 110-114. 18 - 19 September 2015, Zagreb-Croatia

Kusuma dan Dwitagama. 2010. Penelitian Tindakan Kelas. Jakarta: PT Indeks.

Muhson, Ali. (2010). Pengembangan Media Pembelajaran Berbasis Teknologi Informasi. Jurnal Pendidikan Akuntansi Indonesia, Vol. VIII. No. 2, 1-10.

Ovando, C. J. and Collier, V. P. 1985. Bilingual and ESL Classroom. New York: McGraw-Hill Book Company.

Paraniti, A. A. I., 2012. Implementasi Model Pembelajaran Bilingual Preview-Review terhadap Kemampuan Berbahasa Inggris dan Hasil Belajar Biologi Ditinjau dari Kemampuan Dasar Berbahasa Inggris Siswa SMA. Artikel. Diterbitkan. Pascasarjana Undiksha: Singaraja.UndangUndang Republik Indonesia Nomor 20 Tahun 2003 Tentang Sistem Pendidikan Nasional. 2003. Jakarta: Depdiknas.

Sagala. 2010. Konsep dan Makna Pembelajaran. Bandung: Alfabeta.

Tirtayani, Magta, Lestari (2017). Journal of Education Technology. Vol. 1 (1) pp. 18-29 